Article

\title{
Effect of Triangular Baffle Arrangement on Heat Transfer Enhancement of Air-Type PVT Collector
}

\author{
Ji-Suk Yu ${ }^{1} \mathbb{D}$, Jin-Hee Kim ${ }^{2} \mathbb{D}$ and Jun-Tae Kim ${ }^{3, *}$ \\ 1 Zero Energy Building Laboratory, Graduate School of Energy Systems Engineering, \\ Kongju National University, Cheonan 31080, Korea; sook1991@smail.kongju.ac.kr \\ 2 Green Energy Technology Research Center, Kongju National University, Cheonan 31080, Korea; \\ jiny@kongju.ac.kr \\ 3 Department of Architectural Engineering, Kongju National University, Cheonan 31080, Korea \\ * Correspondence: jtkim@kongju.ac.kr; Tel.: +82-41-521-9333
}

Received: 4 August 2020; Accepted: 7 September 2020; Published: 10 September 2020

\begin{abstract}
A Photovoltaic Thermal (PVT) Collector is a device that produces electricity and simultaneously uses a heat source transmitted to back side of the Photovoltaic (PV). The PVT collector is categorized into liquid-type and air-type according to the heating medium. As an advantage, air-type PVT system is easy to manage and can be directly used for heating purposes. The performance of air-type PVT collector is determined by various factors, such as the height of air gap and air flow path (by baffles) in the collector. Baffles are installed in the PVT collector to improve the thermal performance of the collector by generating turbulence. However, the air flow that affects the performance of the PVT collector can vary depending on the number and placement of the baffles. Thus, the flow design using baffles in the collector is important. In this study, the performance of an air-type PVT collector due to the arrangement of triangular baffles and air gap height at the back of the PV module is analyzed through a simulation program. For this purpose, Computational Fluid Dynamics (CFD) analysis was performed with an NX program to compare and analyze the optimum conditions to improve the performance of the collector.
\end{abstract}

Keywords: air-type PVT collector; CFD (computational fluid dynamic); thermal performance; triangular baffles

\section{Introduction}

Globally, the use of sustainable energy is increasing, and among renewable energy systems, solar energy and wind power systems are widely used. Especially, solar energy system is classified into a PV system, a solar thermal system, and a photovoltaic/thermal (PVT) system, and it operates by converting solar energy into electricity and thermal energy. However, a system that uses solar energy cannot be completely dependent on power generation and heat collection as it is not uniform. Therefore, it is applied as a method of stably supplying electricity and thermal energy to a storage device by charging it to a consumer [1,2], and a method of increasing system efficiency, such as harvesting more energy by hybridizing with a fossil fuel system such as natural gas [3].

PVT collectors are device that use heat generated at the back of a PV at the same time as the electricity produced at the front of the PV. PVT collectors are classified into air and liquid types according to the fluid used as the heat transfer medium. Air-type PVT collectors have the advantage of being easy to manage. Previous studies focused on improving the collector's own thermal and electrical efficiency through design, simulation, modeling and experimentation of air-type PVT collectors.

For instance, one review paper of previous studies considered results of air flow and single/double flow paths of various air-type PVT systems and various absorbers (i.e., fin, V-groove, round 
tube, etc.) $[4,5]$. Conclusions showed that the electrical efficiency was $10 \%-25 \%$ and the thermal efficiency was $40 \%-70 \%$. Exergy efficiency was also in the range of $5 \%-25 \%$. Riffat et al. [6] studied parameters affecting the electrical and thermal performance of various types of PVT systems. Parameters examined included the optimal flow rate inside the PVT collector, the presence or absence of a thermal absorber plate, and the thickness of the air layer. In particular, the thermal absorber plate was found to have the most influence on the thermal efficiency of the PVT system. In other studies, it was concluded that as the number of baffles increased, the thermal efficiency increased, but this increase in thermal efficiency decreased above a certain number of baffles $[7,8]$. So, it is necessary to set a proper number of baffles in consideration of the pressure drop.

Based on the CFD program (i.e., ANSYS Fluent), Chaube et al. [9] analyzed shape, viz. rectangular, square, chamfered, triangular and semicircle baffles after simulation in a Reynolds number range of 2900-19,500. Abuska et al. [10] examined the energy, exergy, economics and environmental performance of air-type collectors with V-groove-shaped protrusions. The thermal and exergy efficiencies ranged from $43 \%$ to $60 \%$ and $6 \%$ to $12 \%$, respectively, and the payback period averaged $4.3-4.6$ years. Experiments showed that the collector's thermal efficiency was about $6 \%$ higher than that of the flat collector. Furthermore, Fudholi et al. [11] studied the exergy and sustainability index of air-type PVT collectors with V-groove shaped protrusions. The exergy efficiency was $13.36 \%$ in theory and $12.89 \%$ according to experimental results.

In the studies by Promthaisong et al. [12], triangular ribs were applied to the thermal absorber plate and analyzed in the Reynolds number range of 3000-20,000. The influence of blockage ratio and the pitch ratio of the rib were analyzed as variables. Compared to general collectors, the coefficient of friction and Nusselt number increased by 1.01-4.93 times and 1.02-3.86 times, respectively, by promoting heat transfer. Other studies concluded that when there was a gradient baffle, the maximum enhancement in thermal and effective efficiency were $22.4 \%$ and $18.1 \%$ in the mass flow rate of $0.045 \mathrm{~kg} / \mathrm{s}$ compared to general Solar Air Heater (SAH) [13]. In the studies by Bhagoria et al. [14], an air heater with a wedge (triangle) type baffle was designed, and the heat transfer and friction coefficients were analyzed through experiments. The parameters of the baffle were set as the baffle height, angle and baffle spacing; Nusselt number increased up to 2.4 times compared to that of the collector without baffles. In addition, the friction coefficient increased as the angle of the baffles increased, and the heat transfer performance was highest when the baffle angle was $10^{\circ}$. Yadav et al. [15] investigated the heat transfer inside the collector by installing a triangle baffle on the absorber plate using CFD (ANSYS Fluent). Nusselt number increased with increasing Reynolds number, and was 1.4-2.7 times higher than without a baffle collector. To optimize the triangular baffle, thermal performance was compared and analyzed through CFD simulation using the baffle height, pitch, height ratio and distance ratio between the baffles as variables. The Nusselt number decreased as the distance ratio increased, and the friction coefficient increased by 3.356 times compared to the reference. For an equilateral triangle baffle with Reynolds number of 15,000, distance ratio between baffles of 7.14 and height ratio of 0.042 , the Nusselt number was 3.073 times that of reference [16]. Bensaci et al. [17] performed numerical/experimental studies according to the baffle arrangement in the collector. The thermal efficiency improved with increasing number of baffles, and the coefficient of friction decreased as the Reynolds number increased. Choi et al. [18] performed CFD analysis under the same conditions by installing several resistors inside an air-type PVT collector. In terms of heat transfer performance, the intersection of triangular baffles led to an improvement of up to 1.86 times.

As described above, the application of a triangular baffle in an air-type PVT collector improves the heat transfer performance. This effect is mainly caused by the generation of a vortex in the air layer by increase of the Nusselt and Reynolds numbers. However, in order to prevent dead space and pressure drop, it is necessary to design the baffle so that the flow inside the air-type PVT collector is smooth. Consequently, baffle must be designed in consideration of the placement conditions of the baffle, so that the flow inside the collector can be smooth and the heat transfer performance can be improved. 
In this study, triangular baffles were installed on a thermal absorber plate in the air gap inside an air-type PVT collector; the thermal characteristics of the baffle arrangement condition were analyzed. For this, the heat transfer, pressure drop, and thermal efficiency of the collector were scrutinized through a simulation program (i.e., NX CFD). The primary purpose was to investigate the effects according to the triangular baffle arrangement applied in the air-type PVT collector.

\section{Air-Type PVT Collector Model for Simulation}

\subsection{Model Design}

The air-type PVT collector designed for this study is shown in Figure 1. The front of the collector is covered with a general PV module; the dimensions are $1011 \mathrm{~mm} \times 1520 \mathrm{~mm}$. The PV module has a cell covering the front surface, as in a conventional module (electrical efficiency is $17 \%$ ), and consists of about 54 mono crystal cells between two layers of glass (G/G module). The air layer (height: $34 \mathrm{~mm}$ ) in the collector has a triangular baffle (width: $82 \mathrm{~mm}$, length: $75 \mathrm{~mm}$, height: $16 \mathrm{~mm}$, angle: $15^{\circ}$ ) that acts as an air flow obstruction, and has a certain spacing and arrangement inside the collector. Thus, the obstacle baffle generates turbulence and is used as an element to increase heat transfer performance.

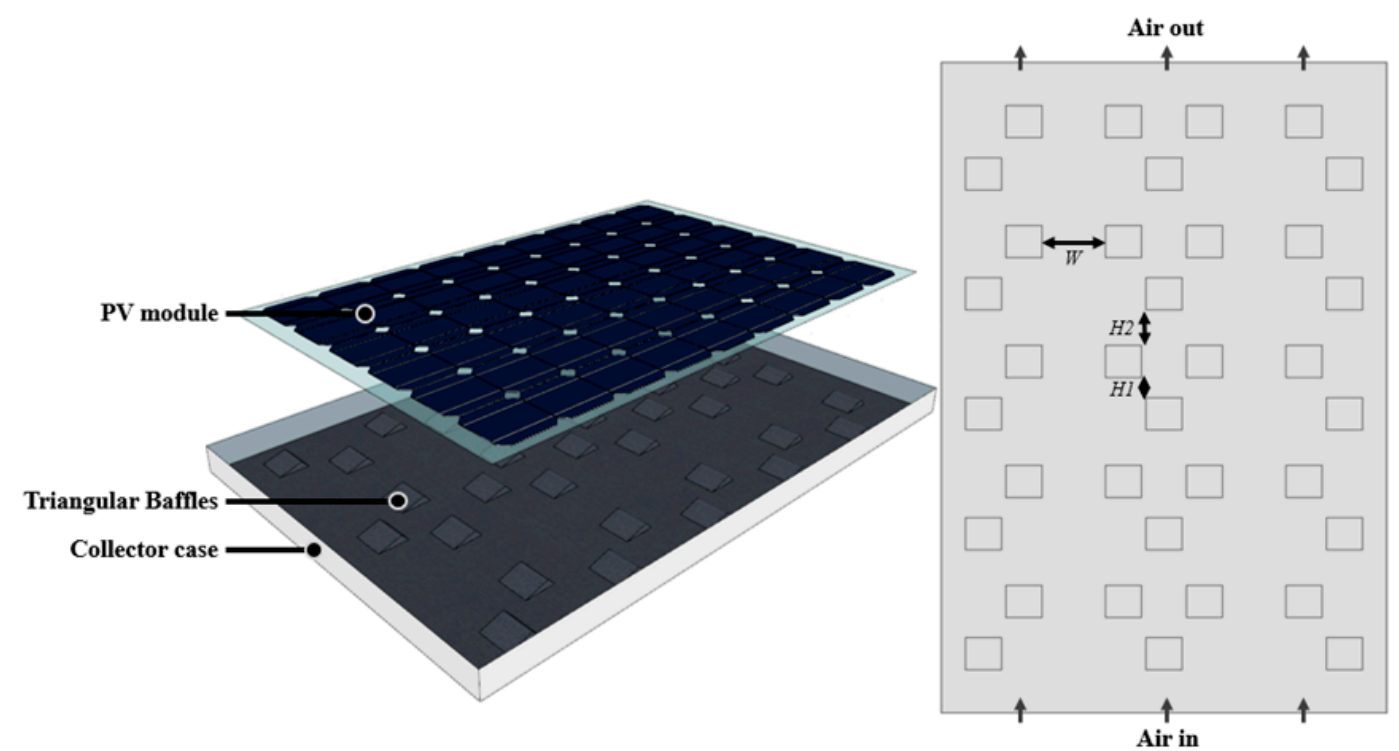

(a)

(b)

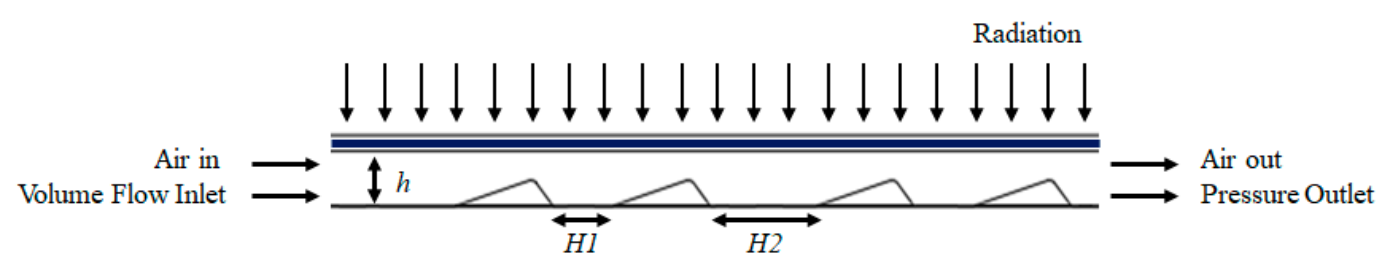

(c)

Figure 1. Concept of Air-type PVT collector with triangular baffles (a) 3D blown-up picture, (b) layout showing baffle positioning, and (c) cross sectional profile showing air flow direction.

The input values of lateral spacing (W) and longitudinal spacing $(\mathrm{H} 1, \mathrm{H} 2)$ of the baffle, which affect the baffle thermal performance, are presented in Table 1 . To adjust the placement of baffles in the collector, three parameters were set: $\mathrm{W}(62,82.5,144 \mathrm{~mm}), \mathrm{H} 1(0,47 \mathrm{~mm})$ and $\mathrm{H} 2(83,130,176.3 \mathrm{~mm})$. In addition, a total of 10 cases were simulated and compared, including a reference to a PVT collector with a baffle-free air layer. 
Table 1. General variables for collector parametric simulation.

\begin{tabular}{|c|c|c|c|c|c|}
\hline Description & Collector Size & $\mathbf{W}[\mathrm{mm}]$ & $\mathrm{H} 1$ [mm] & $\mathrm{H} 2$ [mm] & Number of Baffles [B.No.] \\
\hline Case 1 & \multirow{10}{*}{$1011 \times 1520 \times 34 \mathrm{~mm}$} & & & Reference & \\
\hline Case 2 & & 62 & \multirow{3}{*}{47} & \multirow{3}{*}{83} & \multirow{3}{*}{35} \\
\hline Case 3 & & 82.5 & & & \\
\hline Case 4 & & 144 & & & \\
\hline Case 5 & & 62 & \multirow{3}{*}{0} & \multirow{3}{*}{130} & \multirow{3}{*}{35} \\
\hline Case 6 & & 82.5 & & & \\
\hline Case 7 & & 144 & & & \\
\hline Case 8 & & 62 & \multirow{3}{*}{47} & \multirow{3}{*}{176.3} & \multirow{3}{*}{28} \\
\hline Case 9 & & 82.5 & & & \\
\hline Case 10 & & 144 & & & \\
\hline
\end{tabular}

\subsection{Energy Balance Equations}

The heat transfer process along the cross section of the air-type PVT collector is depicted in Figure 2, in which it can be seen that heat is transferred in the order of the top glass, EVA, PV cell, EVA, bottom glass, air layer, baffle and insulation. However, in this simulation, the heat transfer effect of EVA was insignificant, so only the top and bottom glass layers and PV cells were considered. In Equations (1)-(9), $h_{c v, T}, h_{c v, B}, h_{r d, T}$ and $h_{r d, B}$ are the top and bottom surface convection and radiative heat transfer coefficients of the collector, respectively, $T_{i}$ is the temperature at point $i, T_{\text {sur }}$ is the surface temperature around the collector, $T_{a}$ is the ambient temperature, $R_{i-j}$ is the thermal resistance between points $i$ and $j, h_{r d, i-j}$ is the radiative heat transfer coefficient between points $i$ and $j, S_{i}$ is the amount of solar radiation absorbed at point $i, P_{P V}$ is the amount of power produced by the PV cells, $h_{c v, f T}$ and $h_{c v, f B}$ are the top and bottom surface heat transfer coefficients of the air layer, respectively, and $q^{\prime \prime} u, T$ and $q^{\prime \prime} u, B$ represent the thermal energy recovered from the top and bottom of the collector air layer. Thermal resistance between $\mathrm{ft}$ and $\mathrm{fb}$ was not calculated. The flow in the air-type PVT collector enters at the inlet, sweeps the baffles in the cavity, and passes through it. Therefore, the thermal energy recovered $(q)$ is a factor that affects the thermal performance of the collector more than up and down thermal conduction.

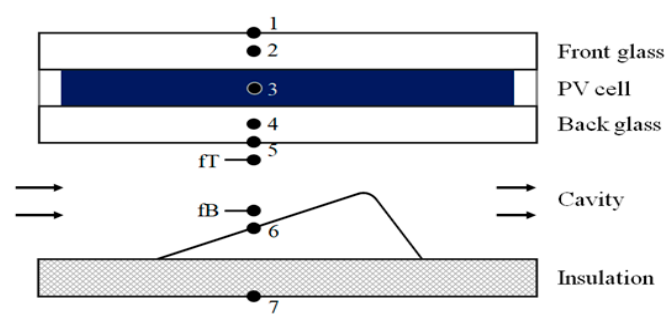

(a)

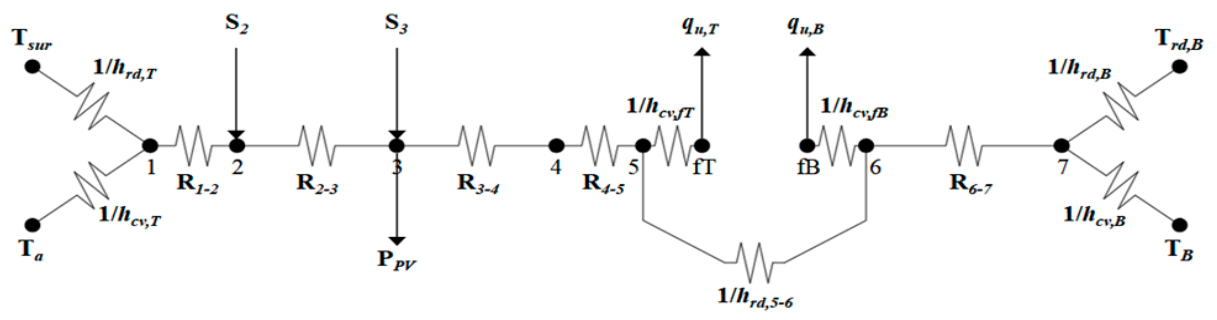

(b)

Figure 2. Heat transfer mechanism: (a) cross sectional view of collector and (b) schematic diagram showing interrelated heat transfer components. 
By performing energy balances in the different nodes of Figure 2, Equations (1)-(12) are obtained [19-23].

The heat transfer equation for the front glass top surface (point 1) is given by Equation (1).

$$
h_{c v, T}\left(T_{1}-T_{a}\right)+h_{r d, T}\left(T_{1}-T_{s u r}\right)+\frac{T_{1}-T_{2}}{R_{1-2}}=0
$$

The heat transfer equation for the front glass middle surface (point 2) is given by Equation (2).

$$
\frac{T_{1}-T_{2}}{R_{1-2}}+S_{2}=\frac{T_{2}-T_{3}}{R_{2-3}}
$$

The heat transfer equation for the PV layer (point 3) is given by Equation (3).

$$
\frac{T_{2}-T_{3}}{R_{2-3}}+S_{3}-P_{P V}=\frac{T_{3}-T_{4}}{R_{3-4}}
$$

The heat transfer equation for the back glass middle surface (point 4) is given by Equation (4).

$$
\frac{T_{3}-T_{4}}{R_{3-4}}=\frac{T_{4}-T_{5}}{R_{4-5}}
$$

The heat transfer equation for the back glass bottom surface (point 5) is given by Equation (5).

$$
\frac{T_{4}-T_{5}}{R_{4-5}}=h_{c v, f T}\left(T_{5}-T_{f T}\right)+h_{r d, 5-7}\left(T_{5}-T_{7}\right)
$$

The heat transfer equation for the fluid in the top portion of the air cavity (point $f T$ ) is given by Equation (6).

$$
q^{\prime \prime}{ }_{u, T}=h_{c v, f T}\left(T_{5}-T_{f T}\right)
$$

The heat transfer equation for the fluid in the bottom portion of the air cavity (point $f B$ ) is given by Equation (7).

$$
q^{\prime \prime}{ }_{u, B}=h_{c v, f B}\left(T_{7}-T_{f B}\right)
$$

The heat transfer equation for the triangle baffle top surface (point 6) is given by Equation (8).

$$
h_{r d, 5-6}\left(T_{5}-T_{6}\right)=h_{c v, f B}\left(T_{6}-T_{f B}\right)+\frac{T_{6}-T_{7}}{R_{6-7}}
$$

The heat transfer equation for the insulation outer surface (point 7) is given by Equation (9).

$$
\frac{T_{6}-T_{7}}{R_{6-7}}=h_{c v, B}\left(T_{7}-T_{B}\right)+h_{r d, B}\left(T_{7}-T_{r d, B}\right)
$$

The thermal resistances for between the top surface and middle of the front glass layer, $R_{1-2}$, and the middle and bottom surface of the back glass layer, $R_{4-5}$ are given by Equation (10). $t h_{g}, t h_{P V}$, $t h_{\text {tri-baffle }}$ and $t h_{\text {insulation }}$ are the thickness of glazing, PV cell, triangular baffles and insulation layers, respectively. $k_{g}, k_{P V}, k_{t r i-b a f f l e}$ and $k_{\text {insulation }}$ are the thermal conductivity of glazing, PV cell, triangular baffles and insulation layers, respectively.

$$
R_{1-2}=R_{4-5}=\frac{1}{2} \frac{t h_{g}}{k_{g}}
$$

The thermal resistances for between the middle of the front glass layer and PV cell layer, $R_{2-3}$, and the PV cell layer and middle of the bottom glass layer, $R_{3-4}$, are given by Equation (11). 


$$
R_{2-3}=R_{3-4}=\frac{1}{2} \frac{t h_{g}}{k_{g}}+\frac{1}{2} \frac{t h_{P V}}{k_{P V}}
$$

The thermal resistances for between the triangular baffles and insulation layer, $R_{6-7}$ are given by Equation (12).

$$
R_{6-7}=\frac{t h_{\text {tri-baffle }}}{k_{\text {tri-baffle }}}+\frac{t h_{\text {insulation }}}{k_{\text {insulation }}}
$$

\subsection{Initial Modeling and Validation}

The air-type PVT collector was installed on the rooftop of an educational building, located in the Cheonan campus of Kongju National University (36.85 N, 127.15 E). The collector was installed on a 2-axis tracker that can be adjusted horizontally (east-west) and vertically to introduce solar radiation into the normal plane. To evaluate the thermal performance, the collector's inlet/outlet temperature, inlet/outlet flow rate, solar radiation, outside temperature, and wind direction/wind speed were measured. The size $(1011 \times 1520 \times 37 \mathrm{~mm})$ and the triangular baffle arrangement case $(\mathrm{W}=104 \mathrm{~mm}$, $\mathrm{H} 1=74.8 \mathrm{~mm}, \mathrm{H} 2=94.8 \mathrm{~mm}$ and B.No. $=35$ ) of the collector used in the experiment are shown in Figure $3 \mathrm{a}, \mathrm{b}$ respectively.

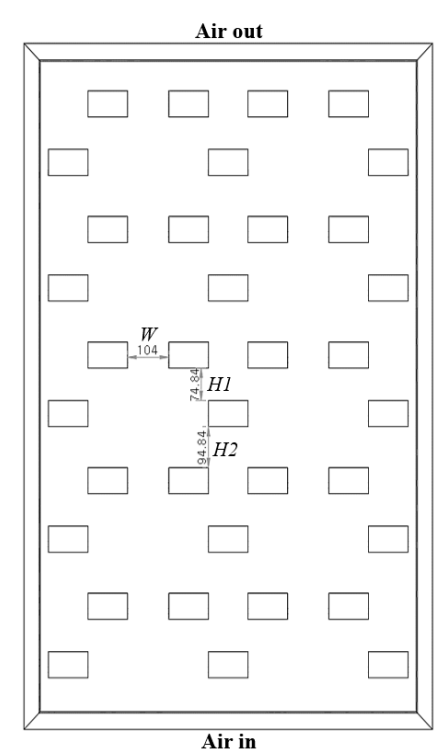

(a)

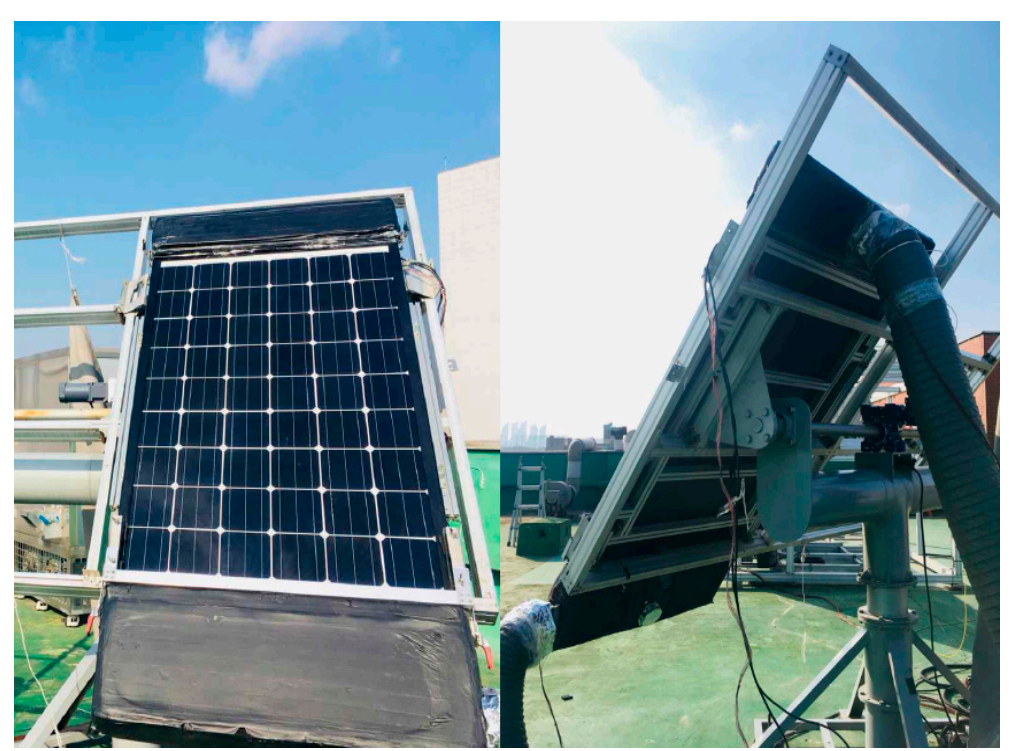

(b)

Figure 3. Air-type PVT collector (a) and (b) Outdoor performance experiment.

Outdoor performance test was performed based on ISO 9806 (Solar energy-solar thermal collectors - test methods). Notably, the solar radiation intensity incident on the collector slope was $700 \mathrm{~W} / \mathrm{m}^{2}$ or higher, and the inlet and outlet flow rates were measured at $100 \mathrm{~m}^{3} / \mathrm{h}$ according to the test method. Experimental data were collected and analyzed for $10 \mathrm{~min}$ when the inlet/outlet flow rate and temperature, and the outside air temperature were in a steady state. Table 2 illustrates a comparison of experiment and numerical results of outlet temperature of the collector.

Table 2. Comparison of experiment and numerical results.

\begin{tabular}{cccccc}
\hline & $\mathrm{G}\left[\mathbf{W} / \mathbf{m}^{2}\right]$ & $\mathrm{T}_{\mathbf{a}}\left[{ }^{\circ} \mathbf{C}\right]$ & $\mathbf{T}_{\text {in }}\left[{ }^{\circ} \mathbf{C}\right]$ & $\mathbf{T}_{\text {out }}\left[{ }^{\circ} \mathbf{C}\right]$ & $\Delta \mathbf{T}\left[{ }^{\circ} \mathbf{C}\right]$ \\
\hline Experimental & 837.83 & 1.5 & 4.86 & 12.79 & 7.93 \\
Numerical (CFD) & 837.83 & 1.5 & 4.86 & 13.04 & 8.18 \\
Error [\%] & - & - & - & $1.92 \%$ & $3.05 \%$ \\
\hline
\end{tabular}


Experimental and numerical data showed that the outlet temperature was $12.79{ }^{\circ} \mathrm{C}$ and $13.04{ }^{\circ} \mathrm{C}$ respectively under the same outdoor conditions, which was almost consistent with an error range of about $1.92 \%$.

$\mathrm{G}$ is solar radiation $(\mathrm{W} / \mathrm{m} 2)$, Ta is ambient temperature $\left({ }^{\circ} \mathrm{C}\right)$, Tin is inlet air temperature of PVT $\left({ }^{\circ} \mathrm{C}\right)$, Tout is outlet air temperature of $\mathrm{PVT}\left({ }^{\circ} \mathrm{C}\right)$, and $\Delta \mathrm{T}$ is Inlet and outlet temperature difference $\left({ }^{\circ} \mathrm{C}\right)$

\subsection{Modeling Conditions and Methodology}

The NX program used for this study has the capability to simulate fluid flow effects, such as CFD modeling, by quickly creating flow zones for complex geometry and performing computational fluid dynamics. In addition, a combination of thermal analysis functions for conduction, convection, radiation and complex heat transfer is performed [24].

Figure 4 shows the mesh of the computational domain, and the tetrahedral method was selected for the meshing strategy. A tetrahedral mesh is set because it has high solution accuracy and has the advantage of reducing simulation time. In addition, to analyze the airflow characteristics around the triangular baffle, the mesh around the baffles was set densely unlike the mesh of the air layer in the collector.

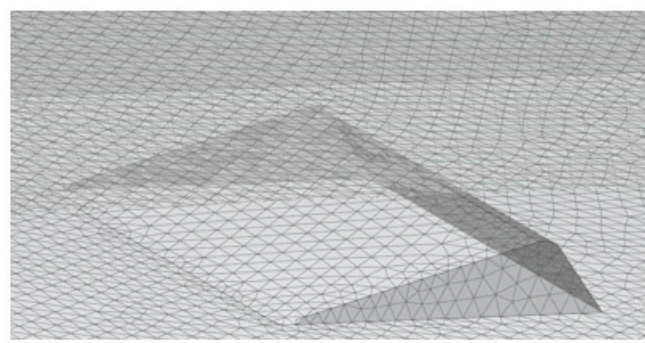

(a)

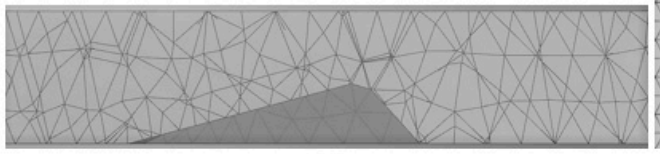

(b)

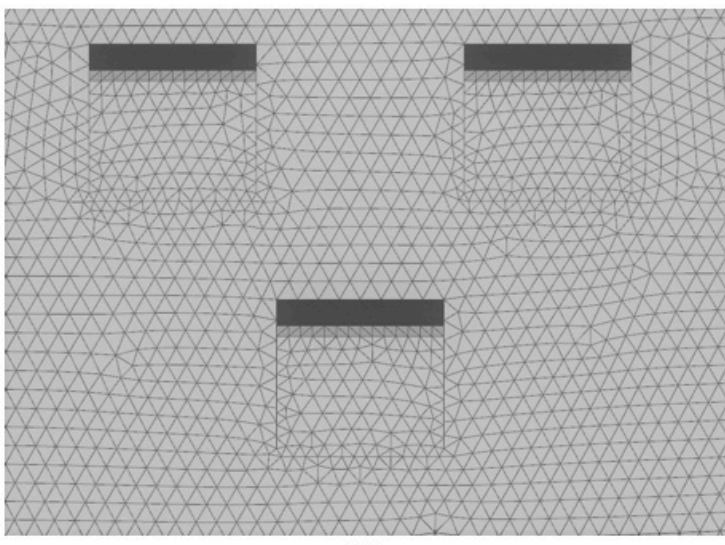

(c)

Figure 4. Demonstrating the mesh of the computational domain: (a) isometric view, (b) cross sectional view, and (c) rear view of the collector.

A grid independence test was performed using the outlet temperature of an air-type PVT collector modeled with $\mathrm{W}=62 \mathrm{~mm}, \mathrm{H} 1=47 \mathrm{~mm}, \mathrm{H} 2=83 \mathrm{~mm}$, B.No. $=35$ as the variables. For the test, the mesh elements were set to four cases $(62,434,119,915,362,677$, and 2,359,170), and the outlet temperature values of the collector were 23.53, 23.32, 23.30 and 23.28, respectively (see Table 3). The result values between mesh elements have a percentage difference of less than approximately $1 \%$. Considering the calculation time, a grid of 362,677 elements was selected as an appropriate grid.

Table 3. Grid independence with the variables $(\mathrm{W}=62 \mathrm{~mm}, \mathrm{H} 1=47 \mathrm{~mm}, \mathrm{H} 2=83 \mathrm{~mm}$ and B.No. $=35)$.

\begin{tabular}{ccc}
\hline Mesh Elements & \left. Outlet Temperature ${\left.\mathbf{~} \mathbf{T}_{\text {out }}\right)}\right)$ & Percentage Deviation of $\mathbf{T}_{\text {out }}$ \\
\hline 62,434 & 23.53 & 0.9775 \\
119,915 & 23.32 & 0.0858 \\
362,677 & 23.30 & - \\
$2,359,170$ & 23.28 & 0.08591 \\
\hline
\end{tabular}

To perform the CFD analysis using the NX program, 10 cases were set with different baffle arrangement as the variables (see Table 1), and the heat transfer, pressure drop, and thermal efficiency of the air-type PVT collector were compared and analyzed. To simulate the collector, the thermal energy of the collector was set to be supplied equally as $700 \mathrm{~W} / \mathrm{m}^{2}$ at $1.54 \mathrm{~m}^{2}$. Furthermore, it was 
input so that the outside air temperature of $7{ }^{\circ} \mathrm{C}$ with mass flow rate of $67 \mathrm{~m}^{3} / \mathrm{h}$ was entered into the inlet of collector. The ambient temperature was input to consider the surface heat loss of the collector, and gravity and buoyancy were applied for modeling the actual air flow. The boundary conditions are summarized in Table 4.

Table 4. Boundary conditions of air-type PVT collector.

\begin{tabular}{cc}
\hline Boundary Condition Parameter & Value \\
\hline Turbulent model & Standard $k-\varepsilon$ model \\
Heat flux & $700 \mathrm{~W} / \mathrm{m}^{2}$ on the PV surface \\
PV area $(\mathrm{L} \times \mathrm{H})$ & $1.54 \mathrm{~m}^{2}(1011 \times 1520 \mathrm{~mm})$ \\
Fluid & Air \\
Inlet, Outlet area of collector & $0.0344 \mathrm{~m}^{2}$ \\
Air in (temperature) & $67 \mathrm{~m}^{3} / \mathrm{h}\left(7^{\circ} \mathrm{C}\right)$ \\
Air out & Pressure Outlet \\
Air density & $1.225 \mathrm{~kg} / \mathrm{m}^{3}$ \\
Buoyancy & Application \\
Gravity & $9.81 \mathrm{~m} / \mathrm{s}^{2}$ \\
Free convection to environment & Application \\
\hline
\end{tabular}

The turbulence model used was the standard K-Epsilon model. It is the most common turbulence model in CFD simulation, and $\mathrm{k}$ is the turbulent kinetic energy and $\varepsilon$ is the dissipation rate of turbulent energy. This model is based on the time-averaged Navier-Stokes equations, which assume that the time-varying velocities of turbulence can be divided into time-averaged velocities and velocity-dependent velocities [25]. Therefore, in the CFD evaluation for this study, air flow analysis was performed using the standard $k-\varepsilon$ turbulence model because the analysis is not complicated and its accuracy is good in terms of computational convergence through air flow simulation data accumulated for a long time.

\section{Analysis of Simulation Results}

\subsection{Heat Transfer Performance}

Figure 5 shows the flow velocity distribution for cases with and without baffles inside the air-type PVT collector. Based on the results, the flow velocity of the reference collector passed to the outlet without stagnation. The collector with a baffle ( $\mathrm{W}=144 \mathrm{~mm}, \mathrm{H} 1=47 \mathrm{~mm}, \mathrm{H} 2=83 \mathrm{~mm}$, B.No. = 35) tended to have a weak local flow rate at the back of the baffle, but the flow rate was significantly faster in the spaces between baffles. Therefore, compared with the reference collector, the internal flow rate of the collector with the baffle was faster and the outlet flow rate increased.

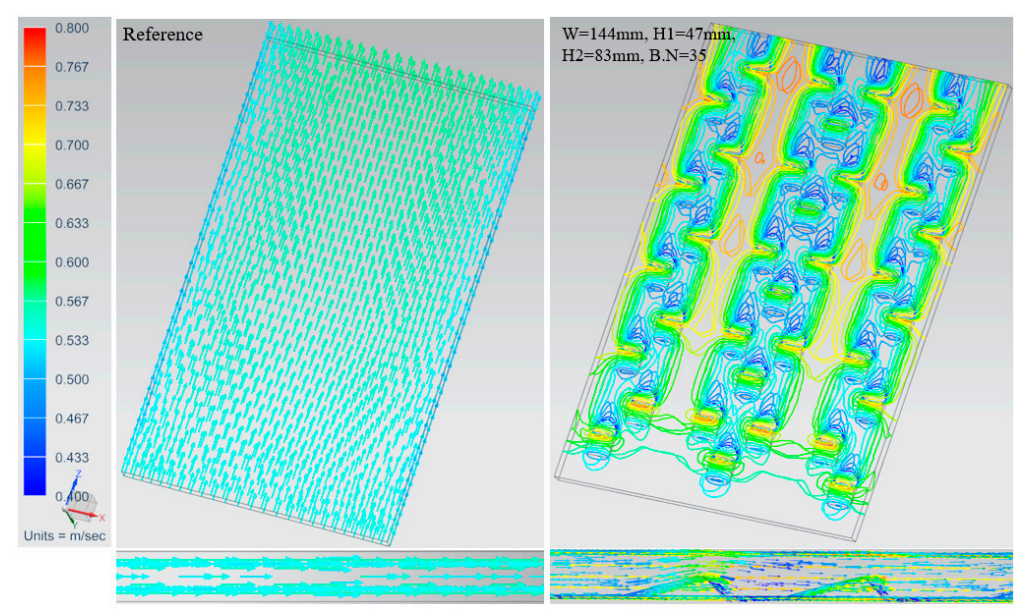

Figure 5. Velocity distribution inside air-type PVT collector: without baffles (left) and with baffles (right). 
Figure 6 shows the temperature distribution inside the air-type PVT collector for cases with and without baffles. In the collector with triangular baffles, the air temperature rose due to locally low flow rate on the back of the baffle, but the space between the top of the baffle and the back of the PV was narrow, causing the air to sweep away quickly. Therefore, it can be deduced that air did not stagnate locally on the back of the baffle and passed quickly to the outlet. As a result, the collector with baffles had a faster outlet flow rate and a higher outlet temperature than the reference collector without baffles, so the former's heat transfer performance was advantageous.
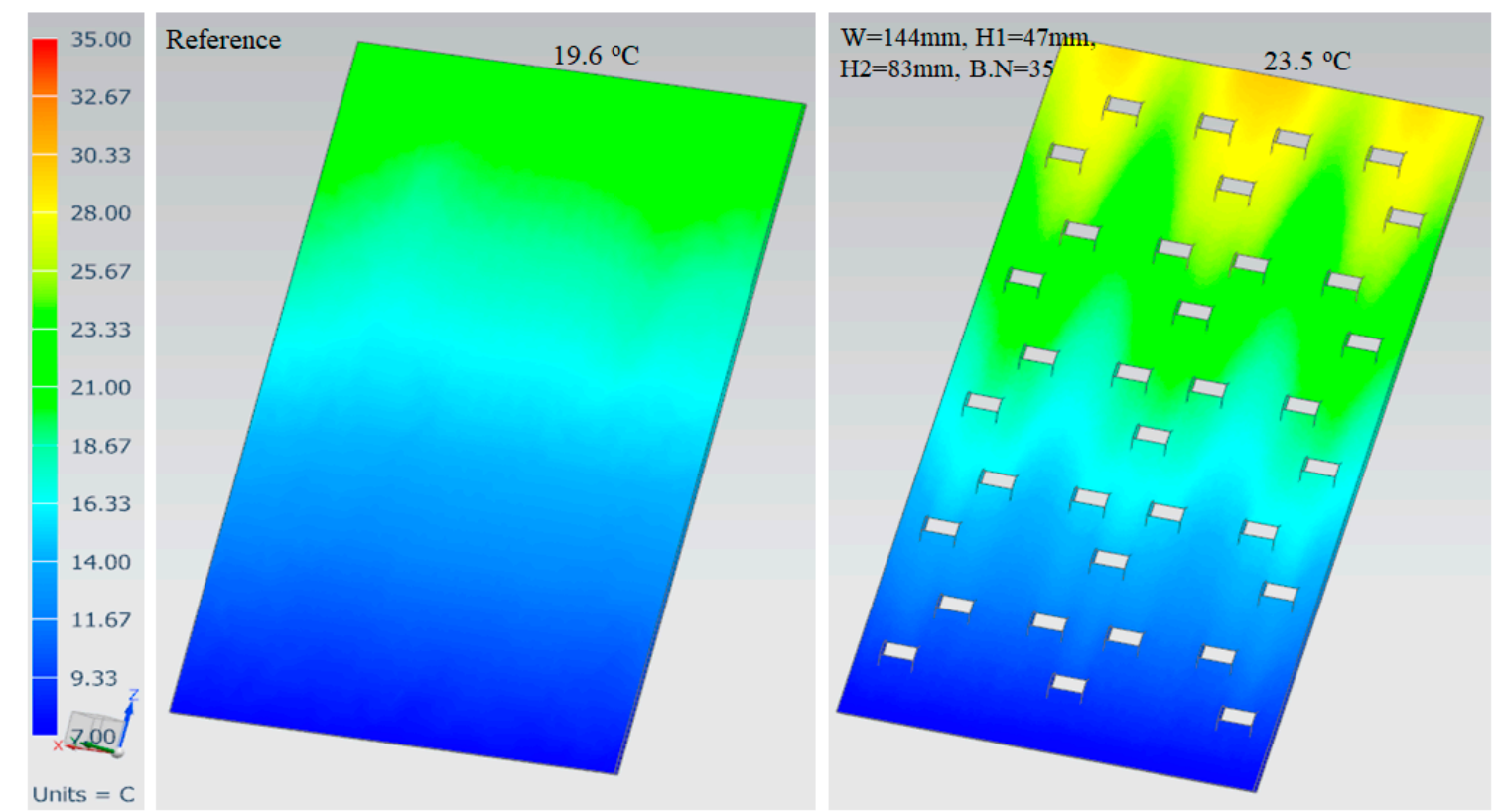

Figure 6. Temperature distribution inside air-type PVT collector: without baffles (left) and with baffles (right).

Figure 7 graphically illustrates the outlet velocity for each baffle arrangement condition of the air-type PVT collector with triangular baffles. The outlet velocity of the collector with the baffle was higher than that of the reference collector $(0.564 \mathrm{~m} / \mathrm{s})$. It was confirmed that the smaller the left and right spacing variable $(\mathrm{W})$ of the baffle was, the faster the outlet velocity and the higher the related average Reynolds number were. This is because only the arrangement was changed in a state in which the baffle size was fixed; as the length of the lateral direction (W) decreased, the flow path became narrower. However, the longer $\mathrm{H} 2$ was, the farther the front and back between the baffles were and the more space was created in the transverse direction. Consequently, the possibility of vortex generation by the baffle was reduced. Consequently, it was seen that the difference in the average Reynolds number range also decreased. Furthermore, the smaller the number of baffles was, the faster was the outlet velocity, but with a correspondingly lower Reynolds number. This is attributed to the flow in the air layer, which was non-uniform; the air flow rapidly passed through the flow paths in the left and right longitudinal directions in the collector with length of $\mathrm{W}$. 


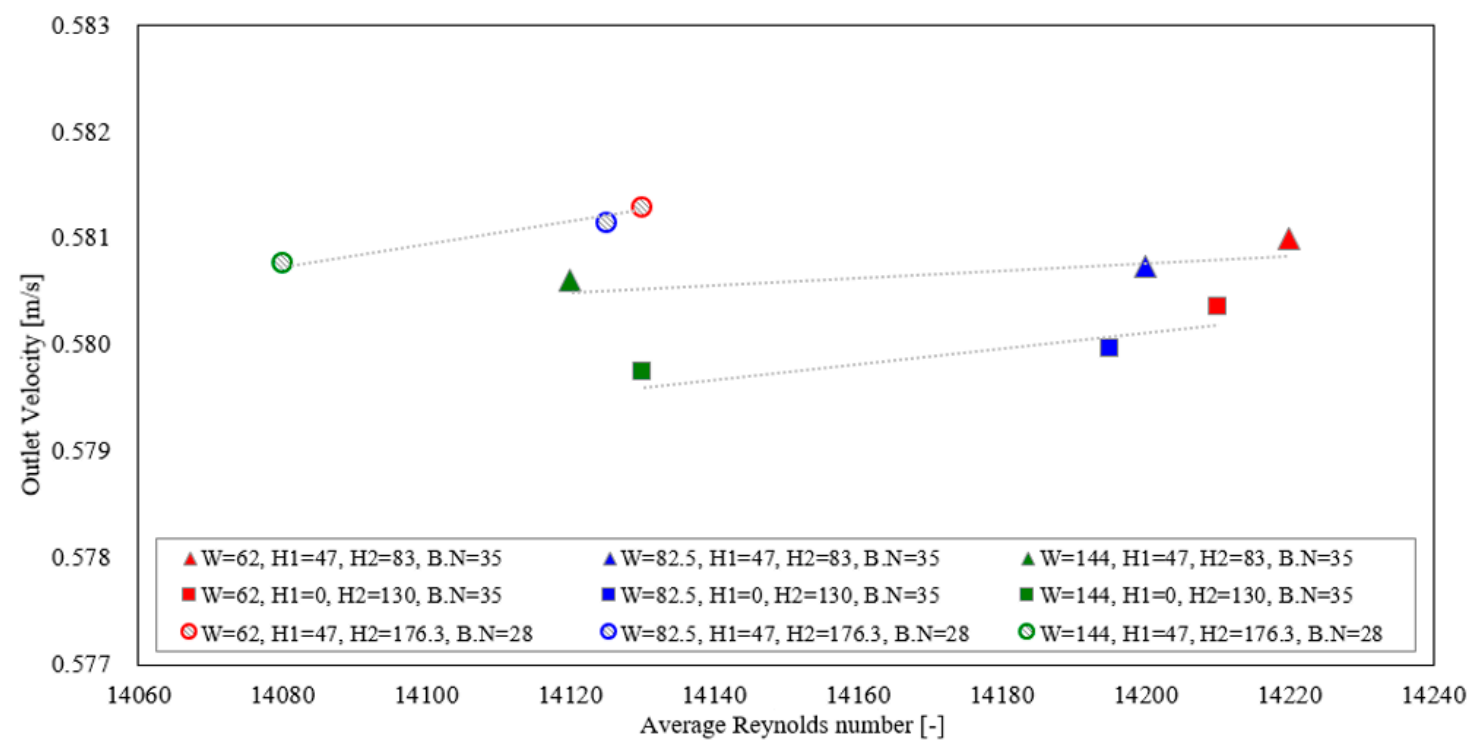

Figure 7. Average Reynolds number and outlet velocity of Air-type PVT collectors.

\subsection{Pressure Drop and Thermal Efficiency}

Figure 8 shows the pressure drop by baffle placement conditions of the air-type PVT collector with triangular baffles. Since the reference collector had no baffles, turbulence did not occur, resulting in a low value of pressure of 0.2302 Pa. The PVT collector with triangular baffles had a pressure drop caused by the baffles. There was a difference in pressure drop value according to the length of $\mathrm{W}$; it can be seen that the longer the distance was between $W$, the more the vortex area decreased and the smaller the pressure drop value was. In addition, the value of number of baffles (B.No.) of 35 led to relatively lower pressure drop than did the value of 28 . It can be concluded that the number of baffles was large, but stagnation areas of air flow occurred less frequently due to the relatively shorter length of H2. Therefore, it was found that the arrangement of the baffles was more favorable than the number of baffles in terms of pressure drop, and the longitudinal spacing of the baffles $(\mathrm{H} 1, \mathrm{H} 2)$ was the main influencing factor.

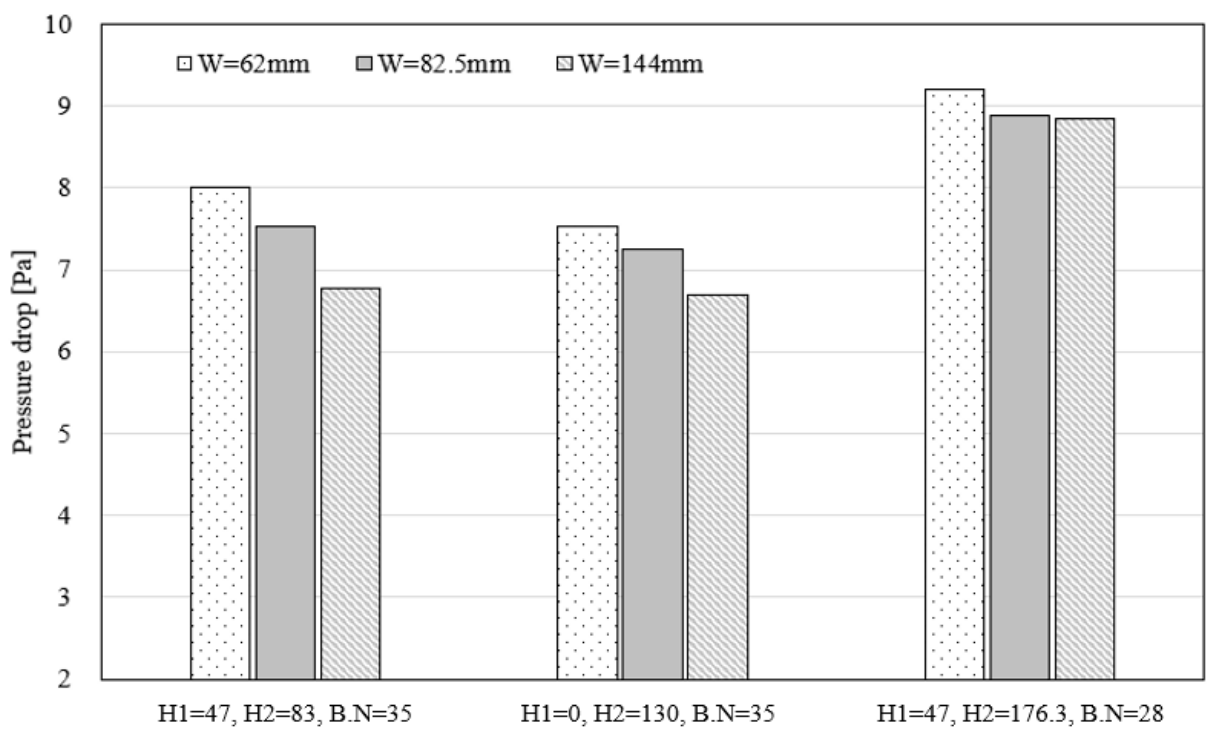

Figure 8. Pressure drop of air-type PVT collector. 
Table 5 shows the thermal efficiency and heat gain according to the arrangement parameters of the air-type PVT collector with triangular baffles. The thermal efficiency of the air-type PVT collector can be calculated by Equation (13) [26], which was deduced by applying the collector's flow rate and inlet/outlet temperature. Based on Equation (10), the reference efficiency without baffles was $26.7 \%$ and the heat gain was $287 \mathrm{~W}$ th. The thermal efficiency of the air-type PVT collector with triangular baffles was in the range of 34.3-35\%, and the heat gain was analyzed to be 369-377 Wth. The collector's thermal efficiency was up to $13.5 \%$ higher than that of the reference collector, and the heat gain was $89.4 \mathrm{Wth}$. According to the baffle arrangement parameters, the thermal efficiency and heat gain were highest when the variable conditions are $\mathrm{W}=144 \mathrm{~mm}, \mathrm{H} 1=47 \mathrm{~mm}, \mathrm{H} 2=83 \mathrm{~mm}$ and B.No. $=35$.

$$
\eta_{\text {th }}=\frac{Q_{2}}{Q_{1}}=\frac{\dot{m} C_{p}\left(T_{\text {outlet }}-T_{\text {inlet }}\right)}{A_{P V T} G}
$$

$A_{P V T}$ is surface area of the collector $\left(\mathrm{m}^{2}\right), \mathrm{G}$ is solar radiation $\left(\mathrm{W} / \mathrm{m}^{2}\right), \dot{m}$ is mass flow rate $(\mathrm{kg} / \mathrm{h})$, $\mathrm{C}_{\mathrm{p}}$ is specific heat of air at a constant pressure $\left(\mathrm{J} / \mathrm{kg}{ }^{\circ} \mathrm{C}\right), \mathrm{T}_{\text {outlet }}$ is outlet air temperature of PVT $\left({ }^{\circ} \mathrm{C}\right)$, $\mathrm{T}_{\text {inlet }}$ is inlet air temperature of PVT $\left({ }^{\circ} \mathrm{C}\right)$, and $\eta_{t h}$ is thermal efficiency (-).

Table 5. Thermal efficiency and heat gain by case of the air-type PVT collector.

\begin{tabular}{|c|c|c|c|c|c|c|}
\hline $\mathbf{W}[\mathrm{mm}]$ & $\mathrm{H} 1$ [mm] & $\mathrm{H} 2[\mathrm{~mm}]$ & B.No. & $\mathbf{T}_{\text {out }}$ & Eff. $_{\text {th }}$ & Heat Gain $\left[W_{t h}\right]$ \\
\hline- & - & - & - & 19.60 & 0.267 & 287.29 \\
\hline 62 & & & & 23.30 & 0.345 & 371.50 \\
\hline 82.5 & 47 & 83 & 35 & 23.29 & 0.345 & 371.30 \\
\hline 144 & & & & 23.52 & 0.35 & 376.70 \\
\hline 62 & & & & 23.24 & 0.344 & 370.30 \\
\hline 82.5 & 0 & 130 & 35 & 23.21 & 0.344 & 369.57 \\
\hline 144 & & & & 23.47 & 0.349 & 375.40 \\
\hline 62 & & & & 23.28 & 0.345 & 371.16 \\
\hline 82.5 & 47 & 176.3 & 28 & 23.23 & 0.344 & 370.07 \\
\hline 144 & & & & 23.32 & 0.346 & 372.07 \\
\hline
\end{tabular}

\section{Conclusions}

To confirm the impact of the arrangement of triangular shaped baffles fitted in an air-type PVT collector, the airflow characteristics in the collector was analyzed through a validated CFD model in this study. The heat transfer characteristics, pressure drop, and thermal efficiency of the collector were examined, and the results can be summarized as follows.

- Depending on the variables, the outlet temperature increased by $3.6-3.9{ }^{\circ} \mathrm{C}$ and the heat gain increased by 1.28-1.31 times compared to the collector without baffles. Therefore, thermal performance of the collector improved up to $31 \%$.

- The thermal performance of the air-type PVT collector improved when the horizontal spacing of the baffles was wider and the vertical spacing was narrower. Furthermore, it was confirmed that greater number of baffles resulted in higher thermal energy yield of the collector.

- The heat transfer performance increased 1.03 times of the maximum outlet velocity and 1.05 times of the average Reynolds number; according to the triangular baffle placement, the pressure drop increased by about $6.78 \mathrm{~Pa}$ under these conditions. Furthermore, variable conditions in which the baffles were more evenly placed (i.e., the case of $\mathrm{W}=144 \mathrm{~mm}, \mathrm{H} 1=47 \mathrm{~mm}, \mathrm{H} 2=83 \mathrm{~mm}$ and B.N = 35) resulted in relatively small pressure drop and high thermal efficiency; thus, these conditions are judged to be advantageous for improving the performance of the air-type PVT collector. 
Based on the results of this study, it can be deduced that the thermal performance improvement according to the staggered arrangement spacing of triangular baffles in the air-type PVT collector was not significant, but it was advantageous in terms of heat transfer in the collector when the baffle spacing was even.

Author Contributions: Conceptualization, J.-S.Y., J.-T.K., and J.-H.K.; methodology, J.-H.K., and J.-S.Y.; software, J.-S.Y.; validation, J.-T.K., J.-H.K. and J.-S.Y.; formal analysis, J.-S.Y.; investigation, J.-H.K. and J.-S.Y.; resources, J.-T.K.; data curation, J.-H.K. and J.-S.Y.; writing-original draft preparation, J.S.Y.; writing-review and editing, J.-T.K., J.-H.K. and J.-S.Y.; visualization, J.-T.K., J.-S.Y.; supervision, J.-T.K.; project administration, J.-S.Y.; funding acquisition, J.-T.K. and J.-H.K. All authors have read and agreed to the published version of the manuscript.

Funding: This research was funded by the Korea Institute of Energy Technology Evaluation and Planning (KETEP) and the Ministry of Trade, Industry and Energy (MOTIE) of the Republic of Korea, grant number 20188550000480 and 20173010013420.

Conflicts of Interest: The authors declare no conflict of interest.

\section{References}

1. Mahamad, M.; Ramadan, M.; Olabi, A.G.; Pullen, K.; Naher, S. A review of mechanical energy storage systems combined with wind and solar applications. Energy Convers. Manag. 2020, 210, 1-14.

2. Lai, C.S.; Jia, Y.; Lai, L.L.; Xu, Z.; McCulloch, M.D.; Wong, K.P. A comprehensive review on large-scale photovoltaic system with applications of electrical energy storage. Renew. Sustain. Energy Rev. 2017, 78, 439-451. [CrossRef]

3. Rashid, K.; Safdarnejad, S.M.; Powell, K.M. Dynamic simulation, control, and performance evaluation of a synergistic solar and natural gas hybrid power plant. Energy Convers. Manag. 2019, 179, 270-285. [CrossRef]

4. Rukman, N.S.B.; Fudholi, A.; Taslim, I.; Indrianti, M.A.; Manyoe, I.N.; Lestari, U.; Sopian, K. Electrical and thermal efficiency of air-based photovoltaic thermal (PVT) systems: An overview. Indones. J. Electr. Eng. Comput. Sci. 2019, 14, 1134-1140. [CrossRef]

5. Mustapha, M.; Fudholi, A.; Yen, C.H.; Ruslan, M.H.; Sopian, K. Review on energy and exergy analysis of air and water based photovoltaic thermal (PVT) collector. Int. J. Power Electron. Drive Syst. 2018, 9, 1367-1373.

6. Riffat, S.B.; Cuce, E. A Review on Hybrid Photovoltaic/thermal Collectors and Systems. Int. J. Low-Carbon Technol. 2011, 6, 212-241. [CrossRef]

7. Bakari, R. Heat transfer optimization in air flat plate solar collectors integrated with baffles. J. Power Energy Eng. 2018, 60, 70-84. [CrossRef]

8. Amraoui, M.A.; Aliane, K. Numerical analysis of a three dimensional fluid flow in a flat plate solar collector. Int. J. Renew. Sustain. Energy 2014, 3, 68-75.

9. Chaube, A.; Sahoo, P.K.; Solanki, S.C. Effect of roughness shape on heat transfer and flow friction characteristics of solar air heater with roughed absorber plate. Trans. Eng. Sci. 2006, 53, 43-51.

10. Abuska, M.; Sevik, S. Energy, exergy, economic and environmental (4E) analyses of flat-plate and V-groove solar air collectors based on aluminium and copper. Sol. Energy 2017, 158, 259-277. [CrossRef]

11. Fudholi, A.; Zohri, M.; Rukman, N.S.B.; Nazri, N.S.; Mustapha, M.; Yen, C.H.; Mohammad, M.; Sopian, K. Exergy and sustainability index of photovoltaic thermal (PVT) air collector: A theoretical and experimental study. Renew. Sustain. Energy Rev. 2019, 100, 44-51. [CrossRef]

12. Promthaisong, P.; Eiamsa-ard, S. Fully developed periodic and thermal performance evaluation of a solar air heater channel with wavy-triangular ribs placed on an absorber plate. Int. J. Therm. Sci. 2019, 140, 413-428. [CrossRef]

13. Sivakandhan, C.; Arjunan, T.V.; Matheswaran, M.M. Thermohydraulic performance enhancement of a new hybrid duct solar air heater with inclined rib roughness. Renew. Energy 2020, 147, 2345-2357. [CrossRef]

14. Bhagoria, J.L.; Saini, J.S.; Solanki, S.C. Heat transfer coefficient and friction factor correlations for rectangular solar air heater duct having transverse wedge shaped rib roughness on the absorber plate. Renew. Energy 2002, 25, 341-369. [CrossRef]

15. Yadav, A.S.; Bhagoria, J.L. A CFD Analysis of a Solar Air Heater Having Triangular Rib Roughness on the Absorber Plate. Int. J. Chem. Tech. Res. 2013, 5, 964-971. 
16. Yadav, A.S.; Bhagoria, J.L. A CFD based thermos-hydraulic performance analysis of an artificially roughened solar air heater having equilateral triangular sectioned rib roughness on the absorber plate. Int. J. Heat Mass Transfer. 2014, 70, 1016-1039. [CrossRef]

17. Bensaci, C.; Moummi, A.; Flor, F.J.S.; Jara, E.A.R.; Rincon-Casado, A.; Ruiz-Pardo, A. Numerical and experimental study of the heat transfer and hydraulic performance of solar air heaters with different baffle positions. Renew. Energy 2020, 155, 1231-1244. [CrossRef]

18. Choi, H.U.; Fatkhur, R.; Kim, Y.B.; Yoon, J.I.; Son, C.H.; Choi, K.H. CFD analysis on the heat transfer performance with various obstacles in air channel of air-type PV/Thermal module. J. Korean Sol. Energy Soc. 2018, 38, 33-43.

19. Othman, M.Y.; Yatim, B.; Sopian, K.; Bakar, M.N.A. Performance studies on a finned double-pass photovoltaic-thermal (PV/T) solar collector. Desalination 2007, 209, 43-49. [CrossRef]

20. Khani, M.S.; Baneshi, M.; Eslami, M. Bi-objective optimization of photovoltaic-thermal (PV/T) solar collectors according to various weather conditions using genetic algorithm: A numerical modeling. Energy 2019, 189, 1-16. [CrossRef]

21. Zhang, G.; Ding, X.; Li, T.; Pu, W.; Lou, W.; Hou, J. Dynamic energy balance model of a glass greenhouse: An experimental validation and solar energy analysis. Energy 2020, 198, 1-18. [CrossRef]

22. Zhao, Y.; Meng, T.; Jing, C.; Hu, J.; Qian, S. Experimental and numerical investigation on thermal performance of PV-driven aluminium honeycomb solar air collector. Sol. Energy 2020, 204, 294-306. [CrossRef]

23. Nourdanesh, N.; Hossainpour, S.; Adamiak, K. Numerical simulation and optimization of natural convection heat transfer enhancement in solar collectors using electrohydrodynamic conduction pump. Appl. Therm. Eng. 2020, 180, 1-10. [CrossRef]

24. Siemens PLM Software, Explore NX and Discover Your Solution. Available online: http://www.plm. automation.siemens.com/products/nx/about-nx-software.shtml (accessed on 4 August 2020).

25. Launder, B.E.; Spalding, D.B. The numerical computation of turbulent flows. Comput. Methods Appl. Mech. Eng. 1974, 3, 269-289. [CrossRef]

26. ISO 9806:2017. International Organization for Standard. In Solar Energy—Solar Thermal Collectors-Test Methods; ISO: Geneva, Switzerland, 2017. 